the government in power in Britain. And one does not have to swallow Thomas McKeown's thesis whole to accept that for health over the past 1000 years two non-medical factorsmalnutrition and overpopulation - have been just as important as the classic killer-infections. General journals should provide objective data about such important tangential issues, and they ignore the important tension between science and social issues at their peril.

A general journal without a social conscience is incomplete, and this is as true today as at any time over the past 150 years. There are suggestions that our society may be suffering from a temporary loss of nerve. The obvious signs are our dirty streets, decaying public transport, and the homeless, unemployed, and mentally ill sleeping rough. Nevertheless, perhaps the less overt features are even more disturbingparticularly Britain's long term failure to provide the education and training needed successfully to compete economically, intellectually, and socially. (As the President of the British Association for the Advancement of Science, Sir Claus Moser, has commented recently, hundreds of thousands of our children have educational experiences not worthy of a civilised nation.)
Doctors will hope that neglect of the public sector is only a temporary aberration, for it is now affecting health. For nearly 50 years Britain has had a truly national service, popular for its equity and its high standards of care, while we still attract doctors from all over the world because of the quality of our postgraduate education. But the social class differences in health have persisted and the NHS itself is now under threat; the question mark that hangs over its future also casts a shadow on many of our other valued institutions. So for the next few years at least the $B M \mathcal{Y}$ 's role is clear: the important and possibly distressing task of documenting the response to these threats to the NHS and the health professions while continuing to publish original clinical research, as well as other features in one form or another. Let us hope that in 2140 a writer will be able to conclude as Peter Bartrip does in his history of the $B M F$ : "Existence has not always been smooth, or progress always onward and upward. But in general the Fournal should be viewed as a success; how else could it have lasted for so long?"

Editor,

STEPHEN LOCK

\title{
What future for the BMA?
}

\section{Promising if it nurtures its provincial roots}

My title has a ring of impertinence. After all, the BMA is as much a British institution as the Test Match or the Foreign Office, and in recent years its image has been enhanced by reports on public health issues and its $£ 2 \mathrm{~m}$ campaign against the NHS review. Yet, as Rudolf Klein argues ( $p$ 700), the profession's influence on the NHS is weakening and it is being seen increasingly as just another pressure group.

So how should the BMA react? Firstly, it should continue its well established functions - campaigning on public health issues and providing professional services to members. But, secondly, and importantly, the association needs to rethink, restructure, and revitalise three key operational aspects: the central craft negotiating machinery, its peripheral structure, and its personal services to members in the regions.

The profession's central representative machinery is complicated: A product of compromises among powerful interest groups, the BMA's constitution and the structures representing the NHS crafts and academic doctors were reviewed in the 1970s by Sir Paul Chambers, a distinguished businessman. His plan for rationalisation nearly wrecked the association. The outcome was that the BMA largely retained a pragmatic constitution that recognises the realities of medicopolitics. But that doesn't mean that its federal structure cannot be improved to meet changing circumstances.

The government intends to devolve power to districts, the new trusts, and family health services authorities. District health authorities and trusts will have considerable freedom to negotiate on the pay and terms and conditions of service of staff, while family health services authorities will have more power than their predecessors to control how general practitioners work. Moreover, the NHS Management Executive and the new health authorities are management orientated with no formal representation from the health professions.

All this leads to two predictions: less internal medical advice for NHS management and a tougher negotiating environment. The government will cut down on central consultations and negotiations - it has already made these difficult and unproductive. So the BMA and the crafts will need to streamline their central committee structure and beef up their local committees. Almost certainly exchanges with Whitehall and the management executive will be confined to broad policy matters-for example, manpower-and (perhaps) to setting a framework for pay and terms and conditions of service with the details filled in peripherally to match market conditions. And the profession would be naive to expect a return to the old system if a Labour government is elected: it will probably welcome this result of Tory policy.

So, by April 1991, when Kenneth Clarke's NHS waddles into its new roles as provider and purchaser of health care, BMA members will be looking to the association for guidance. What, then, should it do?

Ideally, the profession's whole regional and district committee structure should be recast: it is complex, confusing, and variably effective. Perhaps the BMA could initiate an intraprofessional task force, with two main roles: firstly, to coordinate craft representation centrally and locally, and, secondly, to rationalise the way the profession advises the government, the NHS Management Executive, and health authorities on matters such as standards, education, and manpower. This is a tall, controversial, and time consuming order. Meanwhile the BMA should revitalise its own peripheral structure, starting by trying to coordinate the work of existing advisory and negotiating committees. It must also persuade doctors to participate in local committees, no easy task when the new contracts may restrict the time doctors can spend sitting on them.

Twice in the past 15 years the BMA has reviewed its own regional activities. One outcome has been the undoubtedly successful network of provincial secretaries and industrial relations officers. They have advised and supported doctors with contract or staffing problems, reinforced the BMA's local activities, and collected invaluable information. The new style NHS will mean extra work for them: not only will 
there be more local negotiations and more questions about the new contracts but budget holding general practices and doctors employed by trusts will add yet further diversity. These new demands will require resources and manpower. Even if savings are made by streamlining the BMA central committees, members will probably have to pay higher subscriptions for the necessary investment.

What, finally, of the BMA's 200 divisions? These may be its democratic foundation but their activity varies from moderate to near moribund. Many are more social than medicopolitical, fitting uneasily into the local power structure. Yet the divisional structure is a ready made medicopolitical tool with the potential to unify the profession in the districts if only doctors can be persuaded to use it. The time is right for the BMA to inject both money and life into the divisions (and its faltering regional councils) - perhaps with a pump priming honorarium to the honorary secretaries.

Doctors must be convinced that the BMA is more than those peripatetic committee buffs in Tavistock Square: it is overwhelmingly the non-participating members in the divisions. Clearly many aspects of the 1991 NHS are unwelcome, but they provide a stimulus to the BMA to nurture its provincial roots. The Provincial Medical and Surgical Association was founded by provincial doctors fed up with London's dominance; 150 years later a return in their direction is not only opportune but overdue. It could underpin the association's continued prosperity in the twenty first century.

Deputy editor,

GORDON MACPHERSON $B M 7$

\section{Medicine's need for kaizen}

\section{Putting quality first}

Within a couple of decades Japanese industry has come from almost nowhere to dominate world competition. The Japanese can produce goods that are simultaneously cheaper than those of their competitors and of higher quality. What is the secret? Important factors include cheap capital; a long term orientation; a family atmosphere within companies, where workers and managers work together rather than against each other; heavy expenditure on research and development; and government support. But if one factor must be picked out it is kaizen-a commitment throughout most Japanese corporations to continual improvement in quality. ${ }^{1}$ Kaizen is one of the most commonly used words in Japan, and now it is beginning to be heard in corporations from San Francisco to Singapore. The idea is also emerging within medicine, ${ }^{23}$ and there is every prospect that kaizen might do for health care what it has done for Japanese industry.

The idea at the heart of kaizen is that poor quality arises from bad systems rather than bad people. The product is defective not because the worker is lazy or stupid but rather because he or she is inadequately trained, has poor tools, or has insufficient time to do the job-or because of a myriad of possible system defects. To make kaizen work managers must create an environment in which people are enthusiastic to identify deficiencies and work together to right them. Fear must be abolished. "Every defect is a treasure" because once the defect is recognised work can begin on putting it right. Similarly, every patient complaint is a treasure because another key idea with kaizen is that the customer or patient defines quality. These are not the current attitudes within medicine.

Although the customer or patient is king or queen, kaizen begins with process rather than outcome. Ironically, the originators of many of the ideas that have come together to form kaizen were American, ${ }^{+6}$ and they emphasised data and statistical techniques. You start by charting the steps of your process (which is often revelatory in itself) and then measure those steps. You identify where the biggest improvements can be made and begin there on a process of measuring, trying an improvement, measuring again, and so on forever. Perfection is never reached, although you will arrive at a point where there will be more potential for improvement in another part of the system. The aim is to shift the whole process towards greater quality rather than attempt to improve quality by discarding the outliers. Outliers are not, however, ignored, and reasons why the measurements from a particular person, process, or machine are so far removed from the mean will be explored.

This process, which may sound annoyingly theoretical, can be imagined working in circumstances as familiar as British general practice. Imagine that the team wants to improve its preventive care. It defines and measures what it is doing and may decide that the biggest improvements could come in, say, managing high blood pressure. The team again measures what it is doing and discovers, say, that it records the blood pressure in only a small proportion of the men over 40 in the practice; it notices too that some partners do much worse than others. The reasons why some partners perform poorly will need to be explored, but at a team meeting the receptionist might suggest a system of marking the records of those whose blood pressure has not been measured, or maybe the nurse will suggest that she starts a well man clinic. An improvement - and often an unglamorous one - will be tried, and measurement will be repeated. And so the process will continue in an environment that sets great store by continual improvement, encourages people to look for and report defects, and feels happy to measure constantly what is happening. Although I use the fashionable word kaizen, some general practitioners will recognise these activities from their own practices. They are more unusual and probably more difficult in hospitals.

Kaizen's emphasis on process seems to conflict with health care's current emphasis on outcome, and in the United States the outcome proponents and the kaizen enthusiasts are inclined to be rude about each other. This conflict is mistaken, I believe, and we need both kaizen and outcome measures. Although kaizen concentrates on process, it does so merely as the most effective means to the end of a better outcome or produce. And Japanese industry exists within an environment where the outcomes of profit, market share, and stock price are visible to all and where the outcomes of bankruptcy or hostile takeover await those who perform poorly. Similarly, kaizen in health care may make more sense and be more likely to occur in an environment where outcome measures of hospitals and practices are known to all.

But surely kaizen should be more attractive to health workers than the pursuit and punishment of bad apples. We know how difficult it is always to perform well, how much we depend on teams and back up, and how crucial it is to keep learning and trying new ways. A system that helps us in these 